\title{
Studi Penggunaan Silica Fume Sebagai Bahan Pengisi (Filler) Pada Campuran Beton
}

\author{
Reni Oktaviani Tarru *, Bastian Arnanto **, Harni E Tarru *** \\ dan Rosalina Salu Bandaso' **** \\ *Jurusan Teknik Sipil, Universitas Kristen Indonesia Toraja, J1. \\ Nusantara No. 12 Makale 91811, Tana Toraja \\ renarta_trj@yahoo.com
}

**Jurusan Teknik Sipil, Universitas Kristen Indonesia Toraja, Jl. Nusantara No. 12 Makale 91811, Tana Toraja

Email: bastianarnanto.@ymail.com

***Jurusan Teknik Sipil, Universitas Kristen Indonesia Toraja, J1. Nusantara No. 12 Makale 91811, Tana Toraja

Email: eharnit@yahoo.mail.com

****Mahasiswa Teknik Sipil, Universitas Kristen Indonesia Toraja, Jl. Nusantara No. 12 Makale 91811, Tana Toraja

Email: ROS@yahoo.com

\begin{abstract}
Enter an abstract of up to 250 words for all articles. This is a concise summary of the whole paper, not just the conclusions, and is understandable without reference to the rest of the Silica fume merupakan produk sampingan (biproduct) dari suatu proses industri silicon metal. Silica fume mengandung kadar $\mathrm{SiO} 2$ yang tinggi dan merupakan bahan sangat halus, berbentuk butiran, sangat kecil, dan biasanya disePbut dengan mikro silika. Silica fume mengandung unsur $\mathrm{SiO} 2$ lebih dari $85 \%$ dengan
\end{abstract}


demikian silica fume dapat dikategorikan sebagai pozzoland. Terdapat kelebihan tersendiri apabila kita menggunakan silica fume dalam proses pembuatan beton mutu tinggi, kelebihan tersebut antara lain: meningkatkan workabilitas untuk jangka waktu yang lama, meningkatkan stabilitas dan keterpaduan campuran beton segar, Ketahanan beton meningkat drastik, air resapan pada beton banyak berkurang, gas didalam beton banyak berkurang, peningkatan yang besar ketahanan terhadap karbonasi, perembesan klorid dalam beton banyak berkurang, kekuatan awal dan akhir yang tinggi.

Penelitian ini dilakukan dengan membandingkan sampel beton yang dibuat dalam kondisi normal dengan sampel beton yang menggunakan silica fume sebagai bahan pengisi (filler) sebesar 5\%, 10\%, dan 15\% dengan metode eksperimental yaitu melakukan pengujian sampel di Laboratorium.

Hasil penelitian menunjukkan kuat tekan beton normal pada umur 28 hari yaitu 37,10 Mpa, untuk penambahan 5\% silica fume f'c $=40,39 \mathrm{Mpa}$, dan untuk penambahan $10 \%$ silica fume f'c=41,88 Mpa, penambahan 15\% silica fume f'c = 43,62 Mpa.

Kata kunci : Bahan Pengisi, Silica Fume, Kuat Tekan Beton.

\section{PENDAHULUAN}

Beton merupakan bahan konstruksi yang mempunyai peranan yang semakin luas seiring dengan laju pembangunan saat ini. Beton didapat dari pencampuran bahan-bahan agregat halus dan kasar berupa pasir, batu pecah, atau bahan semacam lainnya, dengan menambahkan secukupnya bahan perekat semen, dan air sebagai bahan pembantu guna keperluan reaksi kimia selama proses pengerasan dan perawatan beton berlangsung dan juga bahan tambah (admixture). Bahan tambah ini dapat berupa bahan kimia, serat dan bahan buangan non kimia yang dicampurkan dengan perbandingan tertentu.

Pada beton perlu adanya desain dan kontrol dari komposisi penggunaan material yang mengandung unsur semen (cementitious), agregat, air dan bahan tambah yang tepat. Pemilihan kualitas agregat dan dimensi butiran agregat yang digunakan akan menentukan kekuatan beton yang direncanakan. Penggunaan bahan cementitious termasuk didalamnya portland cement, fly ash, silica fume, dan ampas dari pembakaran butiran tanah pozzolan alam sangat efektif meningkatkan kekuatan dari campuran beton. Beton dengan kualitas yang baik dapat diperoleh dengan penggunaan material yang terkontrol dengan proporsi campuran yang tepat sesuai dengan target atau hasil yang diinginkan, juga diikuti dengan perawatan (curing) yang baik pula.

Silica fume merupakan produk sampingan (biproduct) dari suatu proses industri silicon metal. Silica fume mengandung kadar $\mathrm{SiO}_{2}$ yang tinggi dan merupakan bahan sangat halus, berbentuk butiran, 
sangat kecil, dan biasanya disebut dengan mikro silika. Silica fume mengandung unsur $\mathrm{SiO}_{2}$ lebih dari $85 \%$ dengan demikian silica fume dapat dikategorikan sebagai pozzoland. Terdapat kelebihan tersendiri apabila kita menggunakan silica fume dalam proses pembuatan beton mutu tinggi, kelebihan tersebut antara lain: meningkatkan workabilitas untuk jangka waktu yang lama, meningkatkan stabilitas dan keterpaduan campuran beton segar, Ketahanan beton meningkat drastis, air resapan pada beton banyak berkurang, gas didalam beton banyak berkurang, peningkatan yang besar ketahanan terhadap karbonasi, perembesan klorid dalam beton banyak berkurang, kekuatan awal dan akhir yang tinggi (Technical data sheet Sika Fume, PT Sika Indonesia.

\section{LANDASAN TEORI}

\section{Pengertian Beton}

Menurut SNI-03-2847-2002, pengertian beton adalah campuran antara

semen Portland atau semen hidraulik lainnya, agregat halus, agregat kasar, dan air, dengan atau tanpa bahan tambahan yang membentuk masa padat.

Beton adalah sebuah bahan bangunan yang komposit yang terbuat dari kombinasi agregat dan pengikat semen.

Jenis - Jenis Beton

Ada bermacam - macam jenis beton, yaitu :

a. Beton Ringan adalah beton yang dibuat dengan beban mati dan kemampuan penghantaran panas yang lebih kecil dengan berat jenis kurang dari $1800 \mathrm{~kg} / \mathrm{m} 3$.

b. Beton Massaadalah beton yang dituang dalam volume besar, yaitu perbandingan antara volume dan luas permukaannya besar. Biasanya beton massa dimensinya lebih dari $60 \mathrm{~cm}$.

c. Ferrosemen adalah suatu bahan gabungan yang diperoleh dengan cara memberikan suatu tulangan berupa anyaman kawat baja sebagai pemberi kekuatan tarik dan daktilitas pada mortar semen.

d. Beton Serat (Fibre Concrete) adalah bagian komposit yang terdiri dari dari beton biasa dan bahan lain yang berupa serat. Serat dalam beton ini berfungsi mencegah retak - retak sehingga menjadikan beton lebih daktail daripada beton biasa.

e. Beton Non Pasir (No-Fines Concrete) adalah bentuk sederhana dari jenis beton ringan yang diperoleh dengan cara menghilangkan bagian halus agregat pada pembuatan beton. Tidak adanya agregat halus dalam campuran menghasilkan suatu sistem berupa keseragaman rongga yang terdistribusi di dalam massa beton serta berkurangnya berat jenis beton.

f. Beton Siklop adalah beton normal / beton biasa yang menggunakan ukuran agregat yang relatif besar. Ukuran agregat kasar dapat mencapai $20 \mathrm{~cm}$, namun proporsi agregat yang lebih besar ini sebaiknya tidak lebih dari $20 \%$ agregat seluruhnya.

g. Beton Hampa adalah beton yang setelah diaduk, dituang, dan dipadatkan sebagaimana beton biasa, air sisa reaksi disedot dengan cara khusus yang disebut cara vacuum. Air yang tertinggal hanya air yang dipakai untuk reaksi dengan semen sehingga beton yang diperoleh sangat kuat.

h. Beton Mortar adalah adukan yang terdiri dari pasir, bahan perekat, dan air. Mortar dapat dibedakan menjadi tiga macam, yaitu: mortar lumpur, mortar kapur, dan mortar semen

\section{Material Pembentuk Beton}

Beton terdiri dari beberapa material yang bercampur menjadi satu. Adapun material penyusun dari pada beton adalah :

a. Semen berfungsi sebagai bahan pengikat yang mengikat agregat satu dengan agregat yang lain, sehingga agregat satu dengan agregat yang lain dapat saling mengunci (tidak dapat terpisah). Semakin baik semen yang digunakan maka daya lekatnya akan semakin baik pula.

b. Agregat merupakan material yang memiliki porsi paling besar yang digunakan dalam campuran beton. Dengan kata lain agregat merupakan material utama penyusun campuran beton.

c. Filler dapat berupa soil cement, debu batu, kapur, portland cement, atau bahan lain.

d. Air adalah zat atau materi atau unsur yang penting bagi semua bentuk kehidupan di bumi. Salah satunya adalah dalam hal peombuatan beton.

\section{Pengertian Silica Fume}

Menurut standar Spesification for Silica Fume for Use in Hydaulic Cemen Concrete and Mortar (ASTM-C618-86), silica fume merupakan bahan yang mengandung $\mathrm{SiO}_{2}$ lebih besar dari 85\% dan merupakan bahan yang sangat halus berbentuk bulat dan berdiameter 1/100 diameter semen (Kusumo, 2013).

Menurut Subakti, silica fume mempunyai peranan penting terhadap pengaruh sifat kimia dan mekanik beton. Ditinjau dari sifat kimianya, secara geometris silica fume mengisi rongga-rongga diantara 
bahan semen, dan mengakibatkan diameter pori mengecil serta total volume pori juga berkurang. Sedangkan dari sifat mekaniknya, silica fume memiliki reaksi yang bersifat pozzolan yang bereaksi terhadap batu kapur yang dilepas semen (Kusumo, 2013). Karena kandungan $\mathrm{SiO}_{2}$ yang cukup tinggi, hidrasi air dan semen akan menghasilkan $\mathrm{Ca}(\mathrm{OH})_{2}$ yaitu bahan yang mudah larut dalam air. Kalsium hidroksida $\mathrm{Ca}(\mathrm{OH})_{2}$ ini bereaksi dengan silica oksida $\left(\mathrm{SiO}_{2}\right)$ membentuk kalsium silikat hidrat, dimana $\mathrm{C}$ $\mathrm{S}-\mathrm{H}$ ini mempengaruhi kekerasan beton.

Penggunaan silica fume dalam campuran beton dimaksudkan untuk menghasilkan beton dengan kekuatan tekan yang tinggi. Beton dengan kekuatan tinggi, digunakan,misalnya, untuk kolom struktur atau dinding geser, pre-cast atau beton prategang dan beberapa keperluan lain.

\section{Keuntungan dalam Penggunaan Silica Fume}

Keuntungan dalam penggunaan silica fume dapat ditinjau pada dua kondisi:

1. Saat beton dalam proses pengikatan :

a.) Memudahkan pengerjaan (workability)

b.) Mengurangi perembesan air dan beton (bleeding), dan

c.) Memberikan waktu pengikatan ( setting time) yang lama.

2. Saat beton dalam kondisi keras :

a.) Meningkatkan kuat Tarik

b.) Meningkatkan kuat lentur

c.) Memperkecil susut dan rangkak

d.) Meningkatkan ketahanan terhadap sulfat dan dari lingkungan agresif

e.) Sebagai penetrasi klorida

f.) Permeabilitas lebih kecil, dan 13

g.) Ketahanan terhadap keausan tinggi.

Keuntungan fisik yang diperoleh dari partikel silica fume yang halus untuk menempati ruang yang sangat rapat dengan partikel agregat dengan adonan semen yang merupakan daerah kelemahan dari beton yang merupakan alasan timbulnya efek dinding yang mencegah bersatunya semen Portland dengan permukaan agregat. Bagian ini yang nantinya akan diisi oleh partikel dari silica fume yang sangat halus sehingga air tidak terperangkap didalam partikel padat sehingga sifat menyerap dari daerah bidang pemisah agregat lebih kecil dibanding dengan tanpa silica fume.

Menurut Neville, penggunaan silica fume dengan jumlah yang rendah (dibawah $5 \%$ dari berat semen) tidak menghasilkan kekuatan yang lebih tinggi dari beton karena jumlah silica fume tidak akan mencukupi untuk menutupi permukaan seluruh partikel dari agregat kasar, namun penggunaan silica fume yang menguntungkan juga terbatas tidak lebih dari $10 \%$ dari berat semen yang digunakan, hal ini disebabkan oleh penggunaan silica fume yang berlebih tidak akan dapat menutupi permukaan agregat (Kusumo, 2013).

\section{Uji Kuat Tekan}

Kekuatan tekan merupakan salah satu kinerja utama beton. Kekuatan tekan adalah kemampuan beton untuk menerima gaya tekan per satuan luas. Walaupun dalam beton terdapat tegangan tarik yang kecil, diasumsikan bahwa semua tegangan tekan didukung oleh beton tersebut.

Kekuatan beton mengidentifikasikan mutu dari sebuah struktur. Semakin tinggi tingkat kekuatan struktur yang dikehendaki, semakin tinggi pula mutu beton yang dihasilkan. Kuat tekan diwakili oleh tegangan maksimum f'c dengan satuan Newton per $\mathrm{mm}^{2}$ atau Mpa. Pengujian kuat tekan dilakukan dengan menggunakan Universal Testing Machine dengan kapasitas 1500 kN. Pengujian ini dilakukan berdasarkan ASTM C 469-02.

\section{METODE PENELITAN}

\section{Gambaran Umum Tempat Pengambilan Material dan Lokasi Penelitian}

Salah satu hal yang perlu diperhatikan dalam melakukan penelitian adalah penentuan atau pemilihan lokasi tempat pengambilan contoh (sampel).

a. Agregat halus (pasir)

Agregat halus yang digunakan adalah agregat halus yang berasal dari daerah Maulu (Rembon) $\pm 12 \mathrm{~km}$ dari kota Makale Kabupaten Tana Toraja.

b. Agregat kasar yang digunakan adalah agregat kasar yang berasal dari daerah Eran batu PT.CAT (Carly Alfa Timur) $\pm 2 \mathrm{~km}$ dari kota Rantepao Kabupaten Toraja Utara

c. Silica Fume sebagai bahan pengisi (filler) untuk sampel benda uji beton dapat di pesan atau di beli langsung di Makassar melalui distributor resmi PT Sika Indonesia.

d. Semen yang digunakan semen portland tipe I yaitu semen Tonasa yang banyak terdapat di toko-toko bangunan baik di Tana Toraja maupun Toraja Utara. 
e. Air yang digunakan dalam campuran benda uji adalah air bersih yang bersumber dari Daerah Air Minum (PDAM) Makale, Kabupaten Tana Toraja.

Metodologi Penelitian

Pada penelitian ini akan di buat dua jenis beton yang menggunakan agregat dengan komposisi yang sama namun perekat yang berbeda sehingga waktu proses pembuatan benda uji kedua beton berbeda pula. Pada peoses pertama akan di buat benda uji dari beton konvensional biasa. Setelah perancangan mix design selesai maka dilanjutkan pada pembuatan beton segar untuk pengujian nilai slump demi mengetahui kekentalan campuran sekaligus pembuatan benda uji. Selanjutnya setelah pembuatan benda uji sudah mulai kering (bisa dikeluarkan dari cetakan) cetakan berbentuk kubus $15 \times 15$ x 15, maka proses selanjutnya adalah perawatan benda uji dengan merendam benda uji diangkat dari bak rendaman selama 3, 7, 14, 21 dan 28 hari. Kemudian benda uji diangkat dari bak rendaman untuk dikeringkan sehari sebelum dilakukan pengujian kuat tekan beton. Setelah pengujian selesai maka data diolah untuk diketahui berapa besar kuat tekan beton benda uji. Apabila hasil kuat tekan beton belum mencapai kuat tekan rencana maka kita kembali ke proses mix design sampai hasil kuat tekan memenuhi kuat tekan rencana. Untuk lebih singkatnya dapat dilihat pada bagan alir penelitian.

Pemeriksaan Karakteristik Bahan Campuran

untuk pengujian material pembentuk beton dipakai American Society for Testing and Materials (ASTM)."1993 Annual Book of ASTM Standard" volume 04.02 Concrete and Aggregates. Pemeriksaan di laboratorium dilakukan untuk pengujian sifat - sifat fisik agregat kasar dan agregat halus.

\section{Bahan Penelitian}

a. Agregat halus adalah agregat yang lolos saringan No.8 (2,36 mm) dan tertahan saringan No.200 $(0,075 \mathrm{~mm})$.

b. Agregat kasar disaring dengan saringan sehingga diperoleh agregat kasar yang sesuai dengan rencana dengan butiran-butiran yang tertahan pada saringan No.8 atau 2,36 mm.

c. Semen yang dipakai dalam dalam penlitian ini semen portland tipe I yaitu semen Tonasa

d. Silica fume ini dapat di pesan melalui distributor resmi PT. Sika Indonesia.

e. Air dalam campuran benda uji untuk beton konvensional adalah air bersih yang bersumber dari

Perusahaan daerah Air Minum (PDAM) Makale, Kabupaten Tana Toraja.

\section{Peralatan Penelitian}

Peralatan Pembuatan Benda Uji, Alat yang digunakan dalam pembuatan benda uji adalah

a. Saringan/ayakan dengan ukuran 3', $1 / 2$ ' , , 1 ' 3/4', 3/8', No 4,No 8, No16, No 30, No 50, No 100 ,No200, saringan ini dingunakan untuk memilih dan mengetahui agregat kasar dan halus sehingga di peroleh agregat yang diiginkan.

b. Timbangan

c. Cetakan kubus yang berukuran $15 \times 15$ x 15 cetakan ini akan di pakai sebagai alat pencetak beton yang akan di uji.

d. Talang digunakan sebagai media pencampur dan pengadukan sehingga di peroleh campuran beton yang akan di uji.

e. Sendok spesi, dingunakan untuk mengaduk campuran beton dan untuk memasukkan campuran beton kedalam cetakan.

Pemeriksaan Bahan Dasar

Pemeriksaan bahan dasar yang dilakukan dilaboratorium terdiri dari beberapa bagian, adapun prosedur lengkapnya sebagai berikut:

\section{a. Analisa Saringan Agregat Kasar}

\section{Tujuan percobaan}

Pembagian butir agregat. Data distribusi butiran pada agregat diperlukan dalam perencanaan adukan beton. Pelaksanaan penentuan butir ini dilakukan pada agregat halus dan agregat kasar.Alat yang dingunakan adalah seperangkat saringan atau ayakan tertentu.

\section{Peralatan:}

- Timbangan

- Mesin penggetar saringan

- Oven yang di lengkapi pengatur suhu untuk pemanasan sampai $(110 \pm 5)^{\circ} \mathrm{C}$

- Alat pemisah contoh (sample spilinter)

- Talam- talam

- Kuas, sikat kuningan, sendok dan alat-alat lainya

- Seperangkat saringan dengan ukuran lubang sebagai berikut

Tabel 3.1 Saringan agregat Kasar 


\begin{tabular}{|l|l|l|}
\hline \multirow{2}{*}{ Nomor Saringan } & Ukuran Lubang \\
\cline { 2 - 3 } & Mm & Inch \\
\hline No. 1 & 38,1 & 1,542 \\
\hline No. $3 / 4$ & 19,1 & 0,764 \\
\hline No. $3 / 8$ & 9,52 & 0,38 \\
\hline No. 4 & 4,75 & 0,19 \\
\hline No. 8 & 2,36 & 0,09 \\
\hline No. 30 & 0,60 & 0,024 \\
\hline
\end{tabular}

Sumber: Buku pedoman Penelitian Laboratorium

\section{Prosedur pengujian :}

- $\quad$ Timbang sample yang dingunakan, kemudian oven pada suhu $\pm 110^{\circ} \mathrm{C}$ selama 24 jam.

- Timbang masing-masing saringan.

- Susun saringan pada mesin pengguncang, yang paling bawah adalah pan kemudian saringan yang terkecil dan seterusnya sampai saringan lubang yang terbesar.

- Masukkan benda uji pada saringan teratas kemudian tutup jepit susunan saringan tersebut lalu hidupkan motor mesin pengguncang selama 15 menit.

- Biarkan selama 5 menit untuk membersikan kesempatan debuh-debuh mengendap.

- Buka saringan tersebut lalu timbang berat masing-masing saringan.

- Lanjutkan perhitungan sesui yang tercantum pada formulir.

- Hasil dari pemeriksaan tabel pada lampiaran c

\section{b. Analisa Saringan Agregat Halus.}

\section{Tujuan percobaan}

Menentukan pembagian butir agregat. Data distribusi butiran pada agregat diperlukan dalam perencanaan adukan beton. Pelaksanaan penentuan butir ini dilakukan pada agregat halus dan agregat kasar.Alat yang dingunakan adalah seperangkat saringan atau ayakan tertentu.

\section{Peralatan :}

- Timbangan

- Mesin penggetar saringan

- Oven yang di lengkapi pengatur suhu untuk pemanasan sampai $(110 \pm 5)^{\circ} \mathrm{C}$.

- Alat pemisah contoh (sample spilinter)

- Talam- talam.

- Kuas,sikat kuningan, sendok dan alat-alat lainya

- Seperangkat saringan dengan ukuran sebagai berikut:

Tabel 3.2 Saringan agregat halus

\begin{tabular}{|l|l|l|}
\hline \multirow{2}{*}{ Nomor Saringan } & Ukuran Lubang \\
\cline { 2 - 3 } & Mm & Inch \\
\hline No. 4 & 4,760 & 0,19 \\
\hline No. 8 & 2,380 & 0,095 \\
\hline No. 16 & 1,190 & 0,047 \\
\hline No. 30 & 0,595 & 0,023 \\
\hline No. 50 & 0,279 & 0,011 \\
\hline No. 100 & 0,149 & 0,005 \\
\hline No. 200 & 0,074 & 0,0029 \\
\hline
\end{tabular}

Sumber: Buku pedoman Penelitian Laboratorium

\section{Prosedur pengujian :}

- Timbang sample yang dingunakan, kemudian oven pada suhu $110^{\circ} \mathrm{C}$ selama 24 jam.

- Timbang masing-masing saringan. 
- Masukkan benda uji pada saringan teratas kemudian tutup.jepit susunan saringan tersebut lalu hidupkan motor mesin pengguncang.

- Biarkan selama 5 menit untuk membersikan kesempatan debuh-debuh mengendap.

- Buka saringan tersebut lalu timbang berat masing-masing saringan.

- Lanjutkan perhitungan sesui yang tercantum pada formulir.

- Hasil dari pemeriksaan tabel pada lampiaran D.

\section{c. Pemeriksaan Berat Jenis dan Penyerapan Agregat Kasar}

\section{Tujuan Penelitian :}

Untuk mengetahui berat jenis agregat kasar dan kemampuannya menyerap air.

\section{Peralatan :}

- Gunakan test set

- Saringan no. 4

- Oven

- Pan

Prosedur Penelitian:

- Siapkan benda uji yang tertahan saringan no.4 kurang lebih $5 \mathrm{~kg}$.

- Cuci benda uji tersebut lalu keringkan dalam oven selama 24 jam pada suhu $110^{\circ} \mathrm{C}$.

- Dinginkan dalam ruangan terbuka selama 2 jam lalu rendam dalam air minimal selama 24 jam.

- Buang air rendamannya kemudian tumpahkan agregat diatas kain yang menyerap air. agregat yang besar dikeringkan masing-masing dengan kain lap agar kering permukaan (SSD). lakukan hal ini diruang tertutup sehingga penguapan yang terjadi bisa diabaikan.

- Segera masukkan kedalam keranjang dunagan kemudian celupkan kedalam container yang berisi air.

- Goyang-goyangkan keranjang tersebut dalam air untuk mengeluarkan gelembung-gelembung udara yang terperangkap.

- Timbang berat agregat dalam air (B).

- Keringkan agregat dalam oven selama 24 jam pada suhu $110^{\circ} \mathrm{C}$ setelah didinginkan, timbang berat keringnya (C).

Hitung

Berat jenis (Bulk)

Berat jenuh permukaan $\quad=\quad \underline{A}$

Bearat jenis jenuh (apparent) $=\quad \underline{\mathrm{A}-\mathrm{B}}$

$\frac{\stackrel{C}{C-B}}{\text { C-B }}$

Penyerapan (absorption) $\quad=\frac{\mathrm{A}-\mathrm{C}}{\mathrm{C}} \times 10^{\circ} \mathrm{C}$

\section{d. Pemeriksaan Berat Jenis Dan Penyerapan Agregat Halus}

\section{Tujuan Percobaan}

Untuk menentukan berat jenis agregat halus dan penyerapan agregat halus.

\section{Peralatan:}

- Timbangan ketelitian 0, 1 gram

- Labu ukur $500 \mathrm{ml}$

- Kerucut kuningan (cone)

- Penumbuk (tamper)

- Talam

- Sendok pengaduk

- Oven

- Alat pemisah (sample splinter)

- Saringan no. 4

- Vacum pump

\section{Prosedur percobaan:}

- Ambil benda uji yang lolos saingan no. 4 sekitar 1000 gr.

- Buat perempat agar contoh dapat mewakili, atau gunkan alat pemisah (samplebsplinter), ambil sebanyak 1000gram.

- Masukkan dalam alat pemisah sehingga benda uji tersebut terbagi menjadi dua bagian.

- Keringkan dalam oven pada suhu $110^{\circ} \mathrm{C}$ selama 24 jam lalu dinginkan. 
- Rendam selam kurang lebih 24 jam.

- Tebarkan contoh di atas talam lalu aduk-aduk pada panas matahari sehingga terjadi proses pengeringan yang merata, atau dengan cara dipanaskan di atas kompor.

- Apabila suhu contoh sudah sama dengan suhu ruangan, masukkan kedalam kerucut kuningan dengan tiga bagian, lapisan pertama didapatkan dengan menumbuk sebanyak 8 tumbukan, lapisan kedua sebanyak 8 tumbukan dan lapisan ketiga sebanyak 9 tumbukan. jumlah keseluruhan tumbukan sebanyak 25 kali dengan tinggi jatuh penumbuk $5 \mathrm{~mm}$ diatas permukaan contoh secara merata dan jatuh bebas.

- Bersihkan daerah disekitar kerucut dari butiran agregat yang tercecer.

- Angkat kerucut tersebut dalam arah vertikal perlahan-lahan.

- Amati contoh pada saat dibuka, apabila masih terletak rapih maka contoh masih basah, lalu keringkan kembali, apabila contoh jatuh lapas keseluruhan, maka contoh terlalu kering, ulangi dengan contoh yang baru (tidak boleh ditambah air) berbentuk kerucut, maka contoh tersebut dinyatakan dalam keadaan SSD (saturate surface dry)

- Masukkan dalam pan dan cover untuk menghindari penguapan.

- Amati benda uji yang tercetak tersebut, bila masih terdapat lapisan air dipermukaannya, percobaan diulangi lagi setelah dilakukan pengeringan secukupnya. Bila tidak terdapat lapisa air dipermukaan atas dan terjadi penurunan pada permukaan atas benda uji, berarti sudah tercapai kondisi kering permukaan.

- $\quad$ Isi labu ukur dengan air suling setengahnya lalu masukkan benda uji tadi sebanyak 500gr, jangan sampai ada butiran yang tertinggal, tambahkan air suling sampai 90\% kapasitas labu ukur.

- $\quad$ Gunakan pompa vakum untuk mengeluarkan gelembung-gelembung udara didalamnya.

- $\quad$ Rendam dalam air hingga suhunya mencapai $23^{\circ} \mathrm{C}$ lalu tambahkan air suling sampai tanda batas.

- $\quad$ Timbang dengan ketelitian 0,1 gr (C).

- $\quad$ Cari berat kering benda uji dengan memanaskannya dengan oven selama 24 jam pada suhu $110^{\circ} \mathrm{C}$ (A).

- $\quad$ Isi labu ukur tadi dengan air suling sampai tanda batas lalu timbang dengan ketelitian 0,1 gr (B). Hitung:

Berat jenis

Berat jenis jenuh kering (SSD)

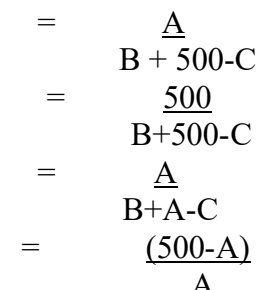

Berat jenis semu

Absorption (Penyerapan

A

\section{e. Pemeriksaan Bobot Isi Agregat}

\section{Tujuan Percobaan:}

Untuk_menentukan berat isi atau bobot isi agregat kasar dan halus dalam kondisi lepas dan padat.

\section{Peralatan:}

- $\quad$ Timbangan dengan kapasitas maksimum $100 \mathrm{~kg}$

- Batang pemadat

- Container pengukur volume

- Meja getar

Prosedur Penelitian:

1. Berat isi kondisi lepas:

- Timbang dan catatlah berat congtainer (A) yang telah diketahui volumenya (V).

- Masukkan campuran agregat kasar dengan hati-hati agar tidak terjadi pemisahan butir, dari ketinggian maksimum $5 \mathrm{~cm}$ diatas pemisahan butir, dengan ketinggian maksimum $5 \mathrm{~cm}$ diatas container dengan mengunakan sendok/sekop sampai penuh.

- Timbang dan catatlah berat countainer + isi (C)

- Hitunglah berat benda uji dengan rumus:

$$
\text { Berat isi }=\frac{\mathrm{C}-\mathrm{A}}{\mathrm{V}}
$$

2. Berat isi padat

- Ambil container isi $(\mathrm{V}=51)$.

- Timbang container (A). 
- Masukkan campuran agregat kasar kedalam container tersebut kurang lebih 1/3 bagian lalu tusuktusuk dengan batang pemadat sebanyak 25 kali.

- Ulangi hal yang sama paada lapisan ke-2 dan ke-3. Kemudian ratakan permukaan benda uji tersebut.

- Letakan di atas meja getar lalu pasang penjepitnya.

- Hidupkan motor penggerak selama 5 menit sampai mencapai pemadatan.

- Ratakan permukaan campuran agregat dengat alat perata. Untuk agregat yang besar ambil kelebihan agregat tangan dan atur sedemikian rupa sehingga volume agregat yang volume rongga dipermukaan.

- Timbang dan catatlah berat wadah + benda uji (C).

Hitung :

Berat isi : $\frac{\mathrm{C}-\mathrm{A}}{\mathrm{V}}$

\section{f. Pemeriksaan Kadar Air Agregat}

Tujuan:

Untuk menentukan kadar air yang terkandung dalam agregat.

Peralatan:

- Cawan kedap air / pan aluminium

- Timbangan ketelitian 0,01 gram

- Oven

- Desikator

- Sample spliter

Prosedur percobaan:

- Gunakan sample spliter untuk pembagian benda uji agar merata.

- Timbang cawan yang akan dipakai lalu beri nomor dengan spidol (A).

- Masukkan benda uji yang akan diperiksa kedalam cawan \pm 100 gr.

- Timbang cawan yang telah berisi benda uji tersebut (B).

- Setelah dikeringkan dalam oven cawan tersebut lalu dimasukkan dalam desikator agar cepat dingin..

- Setelah dingin,timbang kembali cawan yang telah berisi agregat tersebut .

g. Pemeriksaan Kadar Lumpur dan Lempung Agregat

Tujuan:

Peralatan:

Tujuan pemeriksaan ini untuk mengetahui kandungan lumpur dalam agregat.

- Saringan no. 4 dan no. 50

- Timbangan

- Cawan

- Oven

Prosedur penelitian:

- Ambil benda uji dari lapangan dengan menggunkan cara quartering atau gunakan sample spliter untuk pembagian benda uji agar merata.

- Masukkan dalam oven setelah temperatur $110^{\circ} \mathrm{C}$ selama 24 jam.

- Saring benda uji untuk agregat kasar diambil yang tertahan pada saringan no.4 dan untuk agregat halus diambil yang tertahan pada saringan no. 50 .

- Timbang cawan kosong untuk masing-masing benda uji (A).

- Masukkan masing-masing benda uji kedalam cawan, cuci benda uji kotor kering oven tersebut hingga betul-betul bersih.

- Keringkan dalam oven yang dengan temperatur $110^{\circ} \mathrm{C}$ selama 24 jam.

- Masukkan dalam desikator untuk mempercepat pendinginan.

- Timbang cawan + benda uji bersih kering oven (B).

- Hitung kadar lumpur dan lempung:

$$
\frac{\mathrm{A}-\mathrm{B}}{\mathrm{B}} \mathrm{x} 100 \%
$$

\section{h. Pemeriksaan Abrasion Test \\ Tujuan Percobaan}

Untuk mengetahui keausan agregat yang diakibatkan oleh faktor-faktor mekanis dengan menggunakan alat abrasi Los Angeles. 


\section{Peralatan}

- Mesin Los Angeles abrassion machine

- Bola Baja

- Talang

- Saringan No. 12,

- Pan

\section{Prosedur Penelitian}

-Ambil benda uji yang akan dipriksa diambil dan dicuci sampai bersih.

-Keringkan dalam oven selama 24 jam pada suhu temperatur $110^{\circ} \mathrm{C}$ sampai berat tetap.

-Pisahkan agregat tersebut sesuai dengan kelompoknya ( lihat tabel) lalu campurkan sesuai dengankombinasi yang diinginkan dengan berat total 5000 gram (A).

-Power mesin dihidupkan

-Memutar drum abrasi dengan menekan tombol inching sehingga tutupnya mengarah ke atas

-Membuka tutup drum lalumasukkan agregat yang telah dipersiapkan tadi.

-Masukkan bola baja kedalam mesin abrasi los angeles sebanyak yang disyaratkan

-Buka tutup counter lalu mengatur angkanya menjadi 500 dan kemudian tutup kembali.

- Tekan ombol start sehingga mesin berputar dan jumlah putaran akan terbaca pada counter dan drum akan berhenti berputar secara otomatis pada jumlah putaran 500 .

-Buka tutup lalu tekan tombol inching sehingga drum berputar dan agregat serta bola baja tertampung pada talang tersebut.

-Saringlah agregat tersebut dengan saringan No. 12 lalu agregat yang tertahan dicuci sampai bersih.

-Keringkan lagi dalam oven selama 24 jam pada suhu $100^{\circ} \mathrm{C}$.

- Timbang berat keringnya (B).

Perhitungan

$$
\text { Keausan agregat }=\frac{\mathrm{A}-\mathrm{B}}{\mathrm{A}} \times 100 \%
$$

\section{Rencana Campuran Beton}

Rencana campuran dilakukan apabila semua pemeriksaan bahan sudah memenuhi standar SNI dan ASTM. Hal ini dimaksudkan untuk mendapatkan beton yang sebaik-baiknya.

Tujuan perencanaan campuran beton adalah untuk menentukan proporsi semen, agregat kasar serta air yang memenuhi syarat sebagai berikut:

- Kekutan memenuhi yang diinginkan

- Mudah dikerjakan pada saat beton masih segar

- Awet atau tahan terhadap pengaruh lingkungan

- Ekonomis

Dengan mengetahui perencanaan campuran yang akan digunakan dan telah memenuhi syarat spesifikasi maka pelaksanaan percobaan dapat dimulai. Dari setiap percobaan diperiksa nilai Slump, pemakaian semen, perbandingan agregat serta kekuatan beton.

Data-data perencanaan campuran beton dalam penelitian adalah sebagai berikut:

1. Agregat halus yang digunakan adalah pasir alam yang berasal dari daerah Maulu (rembon) Kabupaten Tana Toraja.

2. Agregat kasar yang digunakan adalah batu pecah yang berasal dari daerah Eran batu PT.CAT (Carly Alfa Timur).

3. Semen yang Digunakan Produksi PT. Semen Tonasa dengan jenis semen tipe I.

4. Air yang Digunakan adalah air dari PDAM Makale, Kabupaten Tana Toraja.

5. Silica fume yang digunakan dipenelitian ini bisa di pesan atau di beli langsung di Makassar melalui distributor resmi PT. Sika Indonesia.

\section{Pembuatan dan Perawatan Benda Uji \\ Pembuatan benda uji}

Pembuatan benda uji harus didasarkan pada standar yang berlaku. Pada umunya diameter cetakan kubus berukuran $15 \times 15 \times 15 \mathrm{~cm}$ yang terbuat dari besi.

Langkah kerja:

a. Siapkan peralatan untuk pencampuran beton.

b. Timbang bahan yang digunakan agregat halus, agregat kasar, semen dan terakhir air kemudian taruh ditalang yang sudah disiapkan terlebih dahulu. sesuai dengan urutan penimbangannya.

c.Campurkan bahan beton dibawah talang sampai benar-benar tercampur secara merata.

d. Setelah itu lakukan pengujian slump tes. 
e. Cetakan diisi adukan beton dalam tiga lapisan dengan ukuran yang sama.

f. Pengisian dilakukan secara merata.

g. Tiap lapisan ditusuk-tusuk dengan panjang $60 \mathrm{~cm}$ sebanyak 25 kali (menusukkan dilakukan secara merata pada semua lapisan).

h. Setelah lapisan ketiga selesai ditusuk, penuhi bagian atas cetakan dengan adukan beton kemudian diratakan dengan tongkat perata hingga permukaan. pindahkan cetakan ketempat yang aman.

Perawatan benda uji

Perawatan beton dilakukan untuk menjaga penguapan air yang terkandung dalam beton segar tidak menguap terlalu cepat. Karena apabila penguapan air terjadi terlalu cepat maka itu akan berpengaruh pada proses hidrasi semen dan air berlangsung tidak sempurna.

Langkah kerja:

a. Benda uji kubus dikeluarkan dari cetakan setelah 24 jam sejak pencetakan.

b. Beri tanda pada setiap benda uji agar tidak keliru dengan benda uji yang lain. usahakan benda uji bersih dari kotoran-kotoran apabila ada yang melengket. kemudian timbang benda uji dalam keadaan bersih.

c. Tarik cetakan ditempat yang aman serta usahkan terlindung dari sinar matahari langsung.

d. Setelah menyimpan 24 jam bukalah cetakan benda uji kemudian rendam kedalam air untuk perawatan benda uji selama wakru yang dikehendaki.

\section{Pengujian Kuat Tekan Beton}

Umur dan jumlah benda uji untuk pengujian kuat tekan yang dilakukan terhadap beton yang menggunakan agregat kasar batu pecah yaitu pada umur 3 hari sebanyak 3 buah, 7 hari sebanyak 3 buah, 14 hari sebanyak 3 buah, 21 hari sebanyak 3 buah, dan 28 hari sebanyak 3 buah dengan jumlah bentuk benda uji berbentuk kubus. Jadi total benda uji yang dibuat adalah 15 buah.

Adapun tahapan-tahapan pengujian kuat tekan beton yang dilakukan adalah sebagai berikut:

- Keluarkan benda uji dari tempat perawatannya (bak perendaman sesuai dengan umur rencana).

- Keringkan benda uji.

- Setelah benda uji kering letakan benda uji tepat diatas sumbu, tekan alat uji dan landasan penekanan harus benar-benar bersih.

- Pemberian tekan pada benda uji beton dilakukan secara konstan dan terus menerus hingga benda uji mencapau saat pecah atau retak (jarum penunjuk manometer tidak bergerak naik).

Perhitungan.:

$$
\mathrm{f}^{\prime} \mathrm{c}=\frac{\mathrm{P}}{\mathrm{A}}[\mathrm{Mpa}]
$$

Keterangan;

$$
\begin{aligned}
& \mathrm{f}^{\prime} \mathrm{c}=\text { Kuat tekan beton } \\
& \mathrm{P}=\text { Beton maksimum } \\
& \mathrm{A}=\text { luas penampang benda uji }\left(\mathrm{mm}^{2}\right)
\end{aligned}
$$

\section{Bagan Alir Penelitian}

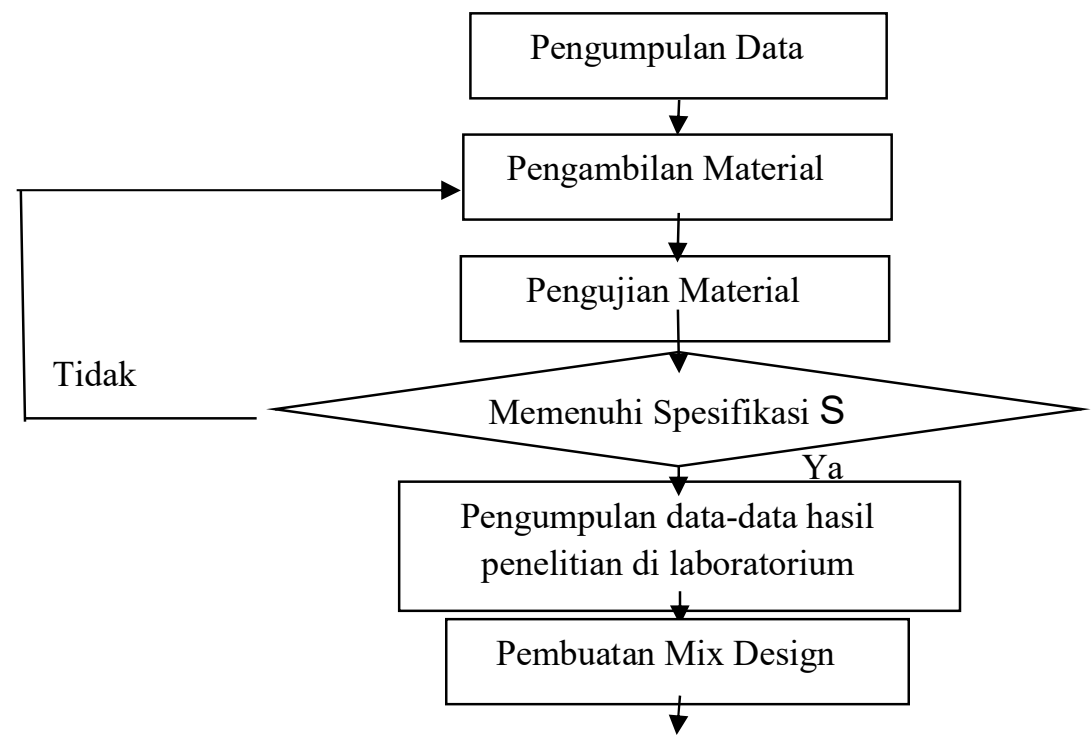


Gambar 3.3. Bagan Alir Penelitian

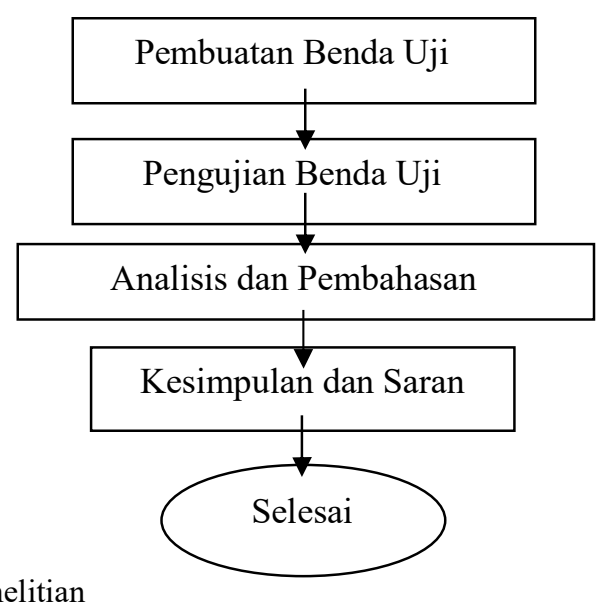

4.

HASIL DAN PEMBAHASAN

Tingkat Kenaikan silica fume dari Beton Normal

\begin{tabular}{|l|l|l|l|}
\hline \multirow{2}{*}{ Umur } & \multicolumn{3}{|l|}{ Silica fume } \\
\cline { 2 - 4 } & $5 \%$ & $10 \%$ & $15 \%$ \\
\hline 3 & $1,8 \%$ & $2,9 \%$ & $3,8 \%$ \\
\hline 7 & $2,5 \%$ & $3,8 \%$ & $5,2 \%$ \\
\hline 14 & $3,2 \%$ & $4,9 \%$ & $6,1 \%$ \\
\hline 21 & $3,9 \%$ & $5,2 \%$ & $7,2 \%$ \\
\hline 28 & $4,2 \%$ & $6,05 \%$ & 8,07 \\
\hline
\end{tabular}

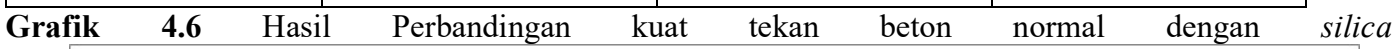

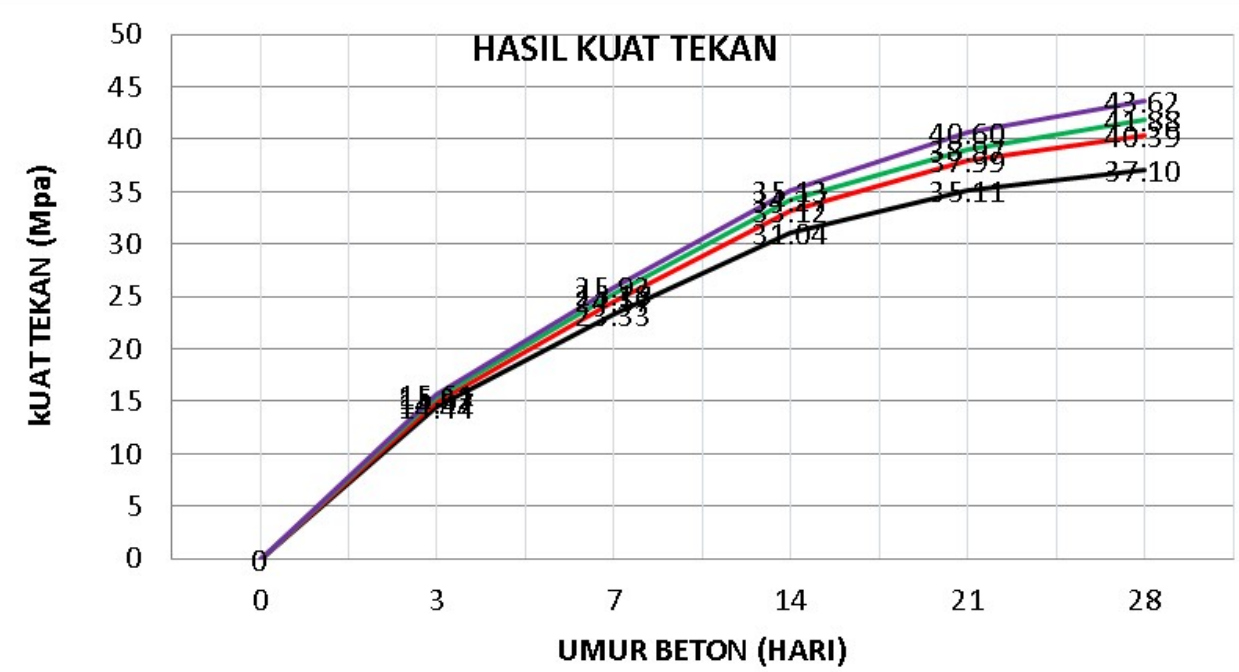

—Beton Normal — - Silica Fume 5\% — Silica Fume 10\% — Silica Fume 15\%

fume

Grafik 4.6 Terlihat bahwa pada hari ke 3 kuat tekan rata-rata benda uji normal sebesar 14,44 Mpa sementara kuat tekan rata-rata benda uji yang menggunakan silica fume 5\%,10\%, dan 15\% sebesar 14,97 Mpa, 15,33 Mpa, dan 15,61. Sementara pada hari ke 7 kuat tekan rata-rata benda uji normal sebesar 
23,33 Mpa sementara kuat tekan rata-rata benda uji yang menggunakan silica fume 5\%, 10\%, dan $15 \%$ sebesar 24,57 Mpa, 25,18 Mpa dan 25,92 Mpa. Pada hari ke 14 kuat tekan rata-rata benda uji normal sebesar 31,04 Mpa sementara kuat tekan rata-rata benda uji yang menggunakan silica fume 5\%, 10\%, dan 15\% sebesar 33,12 Mpa, 34,27 Mpa, dan 35,13 Mpa. Pada hari ke 21 kuat tekan rata-rata 35,11 Mpa sementara kuat tekan tekan rata-rata benda uji yang menggunakan silica fume 5\%, 10\%, dan 15\% sebesar 37,99 Mpa, 37,99 Mpa, 38,97 Mpa dan 40,60 Mpa. Pada hari ke 28 hari kuat tekan rata-rata 37,10 Mpa sementara kuat tekan rata-rata benda uji yang menggunakan silica fume 5\%, 10\%, dan 15\% sebesar 40,39 Mpa, 41,88 Mpa, dan 43,62 Mpa.

\section{SARAN DAN KESIMPULAN}

\section{Kesimpulan}

Berdasarkan data - data dan hasil penelitian yang dilakukan penulis, maka dapat disimpulkan bahwa :

1. Hasil penelitian menunjukkan penambahan silica fume sebagai pengisi campuran beton dapat mempengaruhi kuat tekan beton karena dengan penambahan presentase silica fume kenaikan kuat tekan beton dari normal dengan menggunakan silica fume $15 \%$ pada umur 28 hari pertambahannya sebesar $8,07 \%$.

2. Perbandingan kuat tekan beton normal dan beton dengan penambahan silica fume sebesar $5 \%, 10 \%$, dan $15 \%$ sebagai pengisi (filler) memperlihatkan bahwa kuat tekan beton yang menggunakan silica fume sebesar 15\% lebih tinggi yaitu 43,62 Mpa dibanding kuat tekan beton normal yaitu 37,10 Mpa pada umur 28 hari

Saran

Setelah melakukan penelitian tentang penambahan silica fume sebagai bahan pengisi (filler) dalam pembuatan beton, maka penulis memberikan saran sebagai berikut :

1. Untuk mendapatkan mutu beton yang baik maka dalam pelaksanaan penelitian benar - benar memperhatikan spesifikasi setiap pengujian dengan baik dan teliti.

2. Perlu dilakukan penelitian lebih lanjut untuk memperoleh kenaikan kekuatan beton dengan memperhatikan komposisi penambahan silica fume terhadap campuran beton.

3. Perlu memperhatikan metode pengerjaan beton yang baik dalam penambahan silica fume dalam adukan agar penyebaran silica fume lebih merata.

4. Untuk mendapatkan gambaran secara menyeluruh tentang peningkatan kuat tekan beton yang terjadi apabila menambahkan silica fume dalam campuran beton, maka dibutuhkan penelitian lebih lanjut dengan kuat tekan rencana yang berbeda

5. Diharapkan kepada peneliti selanjutnya untuk perancangan mix design sebaiknya diberi variasi pengunaan bahan tambah agar dapat dilihat besar peningkatan mutu beton yang terjadi.

\section{DAFTAR PUSTAKA}

American Society Fot Tasting And Material (ASTM) C-33-93 section 4

Construction Volume 04.02.1997. Concrete and Aggregates

Adiyono, 2006, Menghitung Konstruksi Beton Untuk Pengembangan Rumah Bertingkat Dan Tidak

Beringkat, Penerbit Penebar Swadaya, Jakarta.

Anonim. 2002. "SNI 03-T-15-2002 Tata Cara Pembuatan Rencana Campuran Beton". Badan

Standarisasi Nasional (BSN). Jakarta

Amri Sjafey, 2005, Teknologi Beton A-Z, Penerbit Yayasan John Hi-Tech Idetama, Jakarta.

Dipohusudu, I. 1999, Struktur Beton Bertulang, Jakarta : Gramedia Pustaka Utama

L.J., Murdock \& Brook K.M. 1986. Bahan Dan Praktek Beton. Penerbit : Erlangga, Jakarta.

Murdock, L.J.D.Sc ; Brook K.M. 1991. Bahan Dan Praktek Beton, Edisi Ke Empat. Penerbit Erlangga, Jakarta.

Irawan,I. 2012. Pengaruh Sika Fume Terhadap Beton Mutu Tinggi Self Compacting Concrete. Tugas Akhir, Jurusan Teknik Sipil, Universitas Pendidikan Indonesia, Jakarta.

Paul Nugraha, Antoni, 2007, Teknologi Beton, Penerbit ANDI, Yogyakarta.

Tambak,I. 2014.'Pengaruh Penggunaan Sika Fume® Sebagai Filler Pada Lapisan Base Course (BC) Campuran Aspal Beton", Tugas Akhir, Jurusan Teknik Sipil, Universitas HKBP Nommensen, Medan

Try Muliono. 2005. Teknologi Beton. Penerbit Andi Yogyakarta.

Tjokro Dimulyono. 1996. Teknologi Beton. Yogyakarta. Nafiri

SNI 03-2847-2002. Tata Cara Perhitungan Struktur Beton Untuk Bangunan Gedung (Beta Version) Cetakan Pertama DPU.

Sebayang,S. 2011. Tinjauan Sifat-Sifat Mekanik Beton Alir Mutu Tinggi Dengan Silica Fume Sebagai Bahan Tambahan. Jurnal Rekayasa, Vol 15 No.2, 131-138 
DYNAMIC SAINT

JDS, Jilid III no. 1, Oktober 2017

Subakti. 1995. Teknologi Beton Dalam Praktek. Jurnal Teknik Sipil, Fakultas Teknik Sipil Dan Perencanaan. ITS, Surabaya.

Sukirman. 2003. Jenis Konstruksi Dan Komponennya.

Susito,I. 2009. Pengaruh Penambahan Sika Fume Terhadap Kuat Tekan Dan Porositas Beton Non

Pasir. Tugas Akhir, Jurusan Teknik Sipil, Politeknik Negri Medan, Medan. 